\title{
Evaluation of Orange Flesh Sweet Potato Varieties (Ipomoea batatas L.) in West Hararghe Zone of Oromia Region, Eastern Ethiopia
}

\author{
Gezahegn Assefa*, Sintayehu Girma, Dereje Deresa \\ Oromia Agricultural Research Institute, Mechara Agricultural Research Center, Horticulture and Spice Research Team, Mechara, Ethiopia
}

Email address:

gezeassefa@gmail.com (G. Assefa)

${ }^{*}$ Corresponding author

\section{To cite this article:}

Gezahegn Assefa, Sintayehu Girma, Dereje Deresa. Evaluation of Orange Flesh Sweet Potato Varieties (Ipomoea batatas L.) in West Hararghe Zone of Oromia Region, Eastern Ethiopia. Biochemistry and Molecular Biology. Vol. 5, No. 3, 2020, pp. 37-43.

doi: $10.11648 /$ j.bmb.20200503.12

Received: April 4, 2020; Accepted: April 22, 2020; Published: October 30, 2020

\begin{abstract}
Sweet potato is an important food security root crop in west Hararghe. it is mainly important for pregnant women and children particularly the Orange fleshed type, which produces storage-carotene, roots precursor of rich in Vitamin A. Therefore, Orange fleshed sweet potato is a promising variety to address the Vitamin A deficiency needs of women and children and to prevent malnutrition in study areas. This experiment was undertaken at Daro labu and Habro districts during 2016-2017 cropping season. The objective of the research was to identify high yielding, adaptable and disease tolerant variety to the study area. A total of three improved Orange fleshed sweet potato varieties; Beletech, Kulfo, Tulla and one local check were used as experimental materials. The experiment was arranged in a Randomized Complete Block Design (RCBD) with three replications. The analysis of variance revealed that there was a significant difference $(\mathrm{p}<0.05)$ among the varieties for growth, yield and yield related trait. The highest mean value of marketable root yield was recorded from Kulfo variety with $\left(15.2\right.$ ton $\left.\mathrm{ha}^{-1}\right)$ and 0.55 ton yield advantage than a local check. During the experimental period, there was low rainfall distribution in west Hararghe, particularly in the study site. Within the existing moisture stress, Kulfo variety was performed well and gave higher root yielder than improved and local check at both locations. In addition to this, the stability analysis result shows that variety Kulfo was the most stable variety across the two sites. Likewise, the yield and yield contributing parameters and stability analysis over location are important selection parameters which can serve as indicators of adaptability of the sweet potato to the study area and can also be utilized for improving in root yield of sweet potato. Therefore, Kulfo variety was selected as high yield in, adaptable and stress tolerant variety under the rainfed condition at Daro labu and Habro districts of West Hararghe.
\end{abstract}

Keywords: Beta Carotene, Orange Fleshed Sweet Potato, Root Length and Root Yield

\section{Introduction}

Orange fleshed sweet potato (Ipomoea batatas L.) is a dicotyledonous plant belonging to the family Convolvulaceae [1]. It can be grown in tropical, subtropical and frost-free temperate climatic conditions. It is among very valuable root crops in Ethiopia and it is widely grown in the eastern, southern and south western parts of the country [2, 3]. The roots are used as a staple food while the vines and leaves are used as animal feed. Orange-fleshed sweet potato varietiesare $\mathrm{m}$ carotene. Increasing the consumption of orange-fleshed sweet potato at the household level can increase supplementation of the diet with vitamin A [4]. Most of the orange-fleshed sweet potato varieties contain-13000 of carotene $\beta$ to $16000 \mu \mathrm{g}$ and this 100 contributes $\mathrm{g}^{-1}$ retinol to activity equivalents (RAE) [5]. Therefore, according to [5], the addition of $100 \mathrm{~g}$ OFSP in a daily diet can prevent VAD in children and significantly reduce the death of mothers. [6] also indicated that a $100 \mathrm{~g}$ OFSP can-carotene, provide which is equivalent more to more than $10006500 \mu \mathrm{g}$ RAE.

In Ethiopia, sweet potato has been cultivated for many years and is important in a diet where population growth is highest and landholding is the least [7]. Over 95\% of the crop is produced in the Southwestern, Eastern and Southern parts 
where it has remained for centuries as one of the major subsistence crops especially in the periods of drought [8]. The most widely grown sweet potato varieties are white-fleshed, with negligible amounts of beta carotene and this could be contributing to vitamin A deficiency [9]. Vitamin A Deficiency (VAD) is widespread and has severe consequences for young children in developing countries [10] including Ethiopia. Although the yield and beta carotene content of white-fleshed sweet potato varieties are low [11] in many countries including Ethiopia, there is a high potential for increasing both the yield and beta carotene content through the use of improved Orange Fleshed Sweet Potato (OFSP) varieties. The OFSP varieties are rich in beta carotene that the body uses to produce vitamin A [11] OFSP varieties are a cheap and year-round source of vitamin A [9] to the poor families in developing countries of East Africa such as Ethiopia because OFSP is well accepted by young children [10] and can combat VAD.

In West Hararghe, availability of the Orange flesh Sweet potato varieties are not evaluated to adaptability. Therefore, evaluation of adaptability for these Orange flesh Sweet potato varieties is important into the study zone to solve food security problem at the same time to combat Vitamin A Deficiency. Therefore, the objective of this experiment was to identify promising and adaptable orange-fleshed sweet potato variety in terms of yield and yield contributing parameters, disease tolerant and hence could combat Vitamin A Deficiency (VAD) at a community level in the tropics of east Ethiopia, at West Hararghe zone.

\section{Methods and Materials}

\subsection{Description of the Study Area}

The experiment was conducted at two locations Daro labu (on station), and Habro districts (Balbaleti PA), under rainfed condition during the 2016-2017 main cropping season. Mechara Agriculture Research Center is located between $8^{\circ}$ 34 ' $\mathrm{N}$ latitude and $4020^{\prime} \mathrm{E}$ longitudes. The altitude of the area is about $1760 \mathrm{~m}$. a. $s$. $l$. It has a warm climate with annual mean maximum and minimum temperature is $31.8^{\circ} \mathrm{C}$ and $14^{\circ} \mathrm{C}$, respectively. The mean annual rainfall is $1100 \mathrm{~mm}$. The soil of the experimental site is well-drained slightly acidic Nitosol. Habro district was located at $404 \mathrm{~km}$ east of Addis Ababa, the capital city of Ethiopia and $75 \mathrm{~km}$ South of Chiro, West Hararghe Zone town. Its place is located at $8^{\circ} 51^{\prime} \mathrm{N}$ and $40^{\circ} 39^{\prime} \mathrm{E}$ and an altitude of the district ranges between $1600-$ $2400 \mathrm{~m}$. a. s. $l$. The mean maximum and minimum temperatures are $20^{\circ} \mathrm{C}$ and $16^{\circ} \mathrm{C}$, respectively. The district receives an annual average rainfall of $650 \mathrm{~mm}$ to $1000 \mathrm{~mm}$. Black sandy and loam soil types are the most dominant soil of Habro District.

\subsection{Experimental Design and Treatments}

Three Orange flesh sweet potato Varieties (Beletech, Kulfo and Tulla), were brought from Hawasa agricultural research center and evaluated with one local check. The experiment was laid out in Randomized Complete Block Design (RCBD) and replicated three times. The plot was $3 \mathrm{~m} \times 3 \mathrm{~m}=9 \mathrm{~m}^{2}$ area and each plots consisting of four rows, which accommodated ten plants per row and thus 40 plants per plot. The spacing between plots and blocks was $1 \mathrm{~m}$ and $1.5 \mathrm{~m}$, respectively.

\subsection{Land Preparation and Planting}

The experimental land was ploughed, harrowed, ridged was prepared before planting. Vine cuttings of $30 \mathrm{~cm}$ length with six nodes were prepared from the healthy stem of each OFSP. Cuttings were planted on the ridges [12] with about three nodes buried in the soil uniformly for all treatments at the spacing of $70 \mathrm{~cm}$ between rows and $30 \mathrm{~cm}$ between plants [13] Weeding, Earthing up and other cultural practices were done according to the standard recommendation for Sweet potato uniformly for all varieties.

\subsection{Data Collected}

Data were recorded on five plants randomly selected from the inner rows of each experimental plot and expressed on per plant basis for each trait under study. The mean of four plants was used for statistical analysis. The following data were recorded: average number of vine per plant, vine length $(\mathrm{cm})$, average root number per plant, root diameter $(\mathrm{cm})$, root length (cm), marketable root yield (ton $\mathrm{ha}^{-1}$ ), unmarketable root yield (ton $\mathrm{ha}^{-1}$ ), and total root yield (ton $\mathrm{ha}^{-1}$ ).

\subsection{Data Analysis}

All collected data were subjected to analysis of variance, for each of the locations and then combined, using SAS software version 9.1. Means that differed significantly were separated using the LSD procedures. Stability of the varieties, the interaction of varieties and environments were analyzed by the GGE Biplot Model.

\section{Results and Discussion}

\subsection{Mean Performance of Varieties-Growth Traits}

The combined analysis of variance across two locations showed significant $(\mathrm{P}<0.05)$ difference among the tested sweet potato varieties for growth traits (vine length and vine number per plant (Table 3 ). The highest mean value of vine length $(103.4 \mathrm{~cm})$ and vine number per plant $(5)$ was recorded from Tulla variety (Table 3$)$, whereas the lowest vine length $(90.00$ $\mathrm{cm}$ ) and vine number per plant (4.58) were recorded from local check and Beletech variety, respectively (Table 3). The variation in vine length of sweet potato varieties at a different location may be due to a response of the genetic characteristics of the varieties to growing environmental factors. The present study is more or less in agreement with the findings of [14] the vine length ranged from 93.3 to $488.7 \mathrm{~cm}$. Moreover, the results of this study are corroborated by the observation of [15] that genetic and environmental factors play a vital role in the root development process. This result is consistent with that of [16] who showed that the number of stems per plant is influenced by 
variety. This might be attributed to genetic differences, which in turn influenced the number of sprouts or eyes on the cutting. In addition, the highest brunch number (13.66) is recorded from accession 4411329.

\subsection{Yield and Yield Related Component}

Root Length: Significant variation was observed among the varieties for root length at Habro, while non significant $(\mathrm{P}<0.05)$ at Mechara and over locations. Local check had the highest root length $(15.66 \mathrm{~cm})$ followed by Beletech variety (12.77). The results are in agreement with the findings of [17] reported that the variety of Daulatpuri produced the highest root length $(14.44 \mathrm{~cm})$.

Root diameter: The root diameter was non-significant at two location Daro labu and Habro districts, while significance $(\mathrm{P}<0.05)$ difference at two sites over location (Table 3). The maximum root diameter $(7.33 \mathrm{~cm})$ was from Kulfo variety at Habro district, whereas the lowest root diameter $(4.3 \mathrm{~cm})$ was from Beletech variety was observed at Mechara on station. There are genetic as well as environmental factors that cause a difference in the size of roots.

Root diameter, non significance difference between varieties, even though, the highest mean root diameter $(6.6 \mathrm{~cm})$ was obtained from Kulfo variety at over two locations (Table 3 ). The difference observed in root diameter among the OFSP varieties is attributed to their genotypic difference. The current result is in conformity with the finding of [18], who conclude that sweet potato variety, H19/06 gave significantly the highest root diameter $(6.92 \mathrm{~cm})$ compared to the other varieties included in their study. Similarly,[19] reported that the highest root diameter $(4.9 \mathrm{~cm})$ was recorded from Tulla variety than local and Beletech varieties.

\subsection{Root Number per Plant, Marketable and Unmarketable Yield}

The varieties significantly differed in root number per plant and marketable root yield, while significantly differed on unmarketable yield at both locations (Table 3). The highest mean value of root number per plant, (6.67) and marketable yield (15.2 t/ha) was recorded from Kulfo variety at two combined over location. The results were significantly difference due to the different variety of oranges fleshed sweet potato. These results are closely related to those reported by [18] the number of root per plant which varied from 1.73 to 6.03 . [20] also found the number of roots per plant varied from 4.70 to 11.76 . The differences in roots yield could be attributed to genetic variations among genotypes in partitioning photosynthesis. Similarly, [19] reported that the highest mean root length was obtained from Tulla variety than Beletech Kulfo and local varieties.

Differences in yield due to the genetic makeup among genotypes have also been reported in other sweet potato trials [21] as well as other crops such as common beans (Phaseolus vulgaris) [22]. Moreover, [3] also reported significant variation between sweet potato genotypes in yield and other desirable traits in their adaptation trial in different agro-ecologies of Ethiopia. Similarly, the differences in marketable root yield could be attributed to the genetic variations among the OFSP varieties in partitioning photosynthesis [21].

Table 1. The means of growth and yield related traits of Orange fleshed Sweet potato at Habro in 2016-2017 cropping season.

\begin{tabular}{|c|c|c|c|c|c|c|c|c|}
\hline Varieties & AVL & ANVPP & ARL & ARD & ARNPP & MY & UNMY & TY \\
\hline Tula & $121.90^{\mathrm{ab}}$ & 2.66 & $10.73^{b}$ & 5.43 & $5.33^{\mathrm{b}}$ & $10.73^{\mathrm{bc}}$ & 0.56 & $11.30^{\mathrm{ab}}$ \\
\hline Kulfo & $116.0^{\mathrm{ab}}$ & 3.83 & $10.20^{\mathrm{b}}$ & 7.30 & $9.33^{\mathrm{a}}$ & $15.57^{\mathrm{a}}$ & 0.43 & $16.0^{\mathrm{a}}$ \\
\hline Beletech & $139.67^{\mathrm{a}}$ & 3.16 & $11.10^{\mathrm{b}}$ & 4.40 & $6.00^{\mathrm{b}}$ & $10.0^{\mathrm{c}}$ & 0.50 & $10.15^{\mathrm{b}}$ \\
\hline Mean & 116.03 & 3.23 & 12.10 & 6.22 & 6.83 & 13.23 & 0.68 & 13.95 \\
\hline CV (\%) & 16.22 & 37.66 & 18.87 & 35.89 & 25.09 & 19.568 & 42.12 & 21.47 \\
\hline LSD $5 \%$ & 34.23 & 2.21 & 4.15 & 4.06 & 3.04 & 4.02 & 2.27 & 5.45 \\
\hline
\end{tabular}

$\mathrm{AVL}=$ Average vine length $(\mathrm{cm})$, ANVPP average number of vine per plant, $\mathrm{ARL}=\mathrm{Average}$ root length $(\mathrm{cm})$, ARD=Average root diameter $(\mathrm{cm})$, $\mathrm{ARNPP}=$ Average of roots number per plant, $\mathrm{MY}=$ Marketable root yield ton $/ \mathrm{ha}, \mathrm{UNMY}=\mathrm{Unmarketable}$ root yield ton $/$ ha, $\mathrm{TY}=\mathrm{Total}$ root yield ton $/$ ha.

Based on the current result we can suggest that variety Kulfo was the best variety for marketing purposes but the two newly introduced OFSP varieties Beletech and Tulla were considered the poorest varieties for marketing purposes [9]. Thus, these are important parameters for selection and serve as indicators of adaptability of the crop to the study area. Accordingly, a variety of Tulla can be used as a good source of marketable roots where production is aimed at marketable roots [13].

Table 2. The mean of growth and yield related traits of Orange fleshed Sweet potato at Mechara, 2016-2017 cropping season.

\begin{tabular}{|c|c|c|c|c|c|c|c|c|}
\hline Varieties & AVL & ANVPP & ARL & ARD & ARNPP & MY & UNMY & TY \\
\hline Tula & 85.0 & 7.33 & 15.33 & 5.13 & $2.00^{\mathrm{b}}$ & $9.80^{\text {ba }}$ & $0.19^{b}$ & $10.0^{\text {ba }}$ \\
\hline Kulfo & 83.33 & 5.33 & 12.66 & 5.90 & $4.00^{\mathrm{a}}$ & $14.83^{\mathrm{a}}$ & $0.25^{\mathrm{b}}$ & $15.08^{\mathrm{a}}$ \\
\hline Beletech & 88.66 & 4.33 & 13.00 & 4.30 & $4.33^{\mathrm{a}}$ & $7.74^{b}$ & $0.12^{\mathrm{b}}$ & $7.87^{\mathrm{b}}$ \\
\hline Mean & 84.53 & 6.46 & 14.23 & 4.786 & 3.38 & 12.80 & 0.234 & 13.04 \\
\hline CV (\%) & 13.16 & 34.02 & 27.07 & 19.32 & 25.73 & 30.17 & 36.77 & 29.75 \\
\hline LSD $5 \%$ & 20.24 & 4.00 & 7.01 & 1.68 & 1.58 & 7.03 & 0.15 & 7.06 \\
\hline
\end{tabular}

$\mathrm{AVL}=$ Average vine length $(\mathrm{cm})$, ANVPA average number of vines per plant, $\mathrm{ARL}=$ Average root length $(\mathrm{cm})$, ARD $=$ Average root diameter $(\mathrm{cm})$, $\mathrm{ATNPP}=$ Average of roots number per plant, $\mathrm{MY}=$ Marketable root yield ton/ha, UNMY=Unmarketable root yield ton/ha. 
Table 3. The mean combined analysis results of growth and yield related traits of Orange fleshed Sweet potato at Daro labu and Habro Districts in 2016-2017

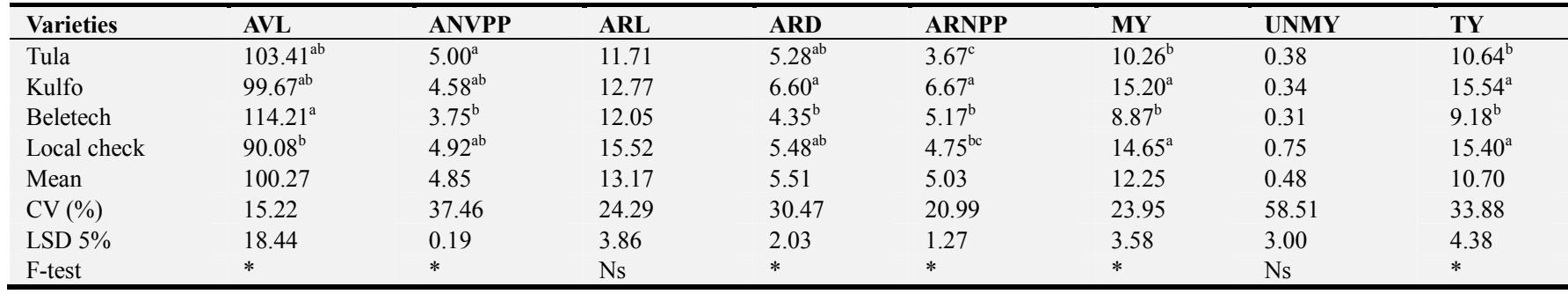

$\mathrm{AVL}=$ Average vine length $(\mathrm{cm})$, ANVPA average number of vine per plant, $\mathrm{ARL}=\mathrm{Average}$ root length $(\mathrm{cm})$, $\mathrm{ARD}=\mathrm{Average}$ root diameter $(\mathrm{cm})$, $\mathrm{ARNPP}=$ Average of roots number per plant, $\mathrm{MY}=$ Marketable root yield ton/ha, UNMY=Unmarketable root yield ton/ha, TY=Total root yield ton/ha.

Unmarketable root yield: Unmarketable root yield was none significantly $(\mathrm{p}<0.05)$ different among the Orange flesh sweet potato varieties (Table 3). Similarly, [19, 13] also observed none significant differences in unmarketable root yield among sweet potato varieties in their study. Even though unmarketable root yield was none significantly different among the orange flesh sweet potato varieties, the highest unmarketable root yield ( 0.89 ton/ha) was recorded from local check at over location in two sites. On the other hand, the lowest unmarketable root yield $(0.31 \mathrm{t} / \mathrm{ha})$ was recorded in (variety Beletech) which is also not significantly different from two varieties (Table 3). [23] had observed wide variation among sweet potato varieties in most of the parameters (number of branches per plant, vine length, fresh fodder weight, and saleable root yield) studied and attributed such differences to genetic composition.

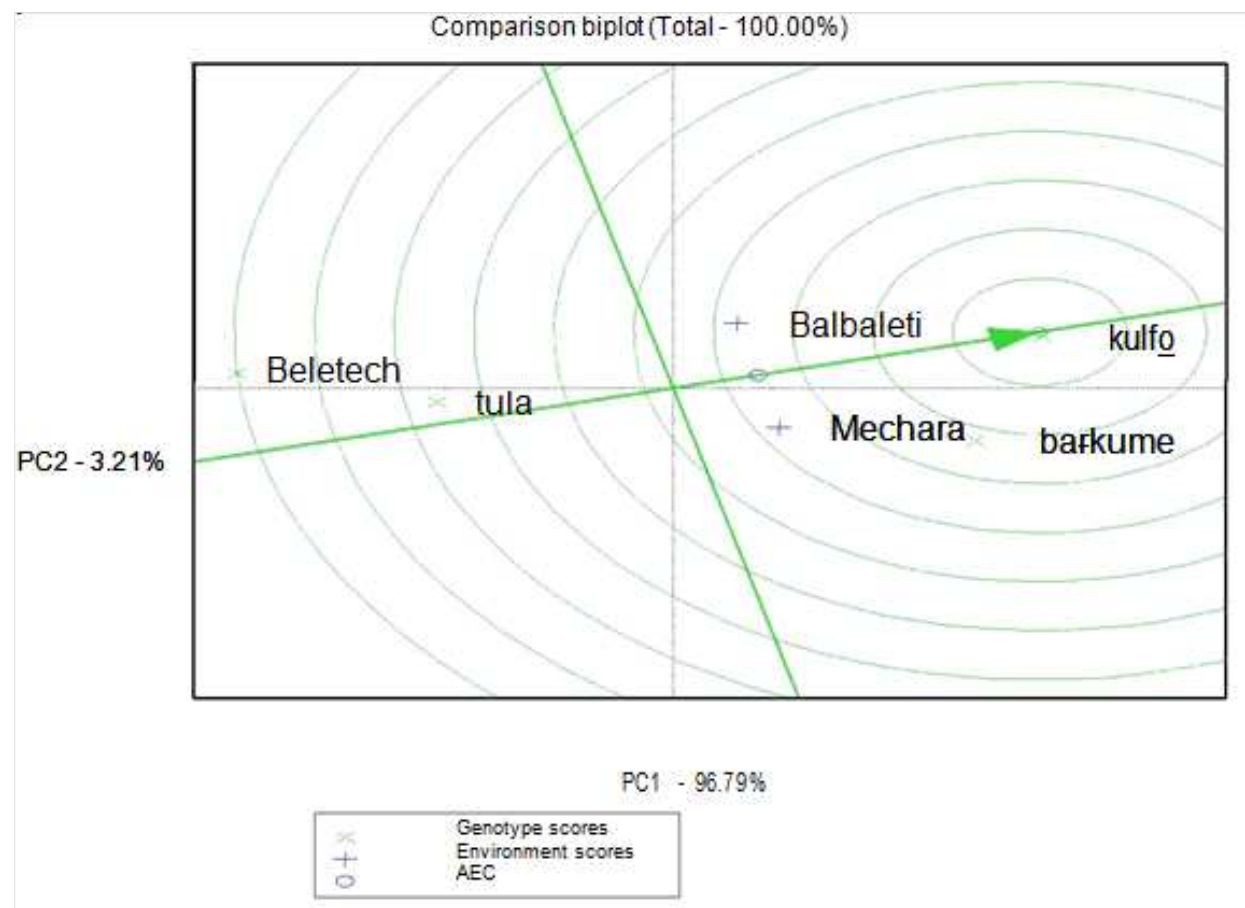

Figure 1. Mean performance of four orange-fleshed sweet potato varieties and their stability across two environments for fresh root yield at West Hararghe zone.

\subsection{Total Root Yield $(t / H a)$}

Total root yield Significant $(\mathrm{p}<0.05)$ difference occurred in total root yield among the orange flesh sweet potato varieties evaluated (Table 2). The highest total root yield (15.54 ton ha $\left.{ }^{-1}\right)$ was recorded in Kulfo variety (Table 3). However, the lowest total root yield (10.64 ton ha ${ }^{-1}$ ) was recorded in Variety Tulla. The differences in total root yield could be attributed to varietal differences among the orange flesh sweet potato varieties [24].

\subsection{Stability Analysis Across Environment}

The GGE-biplot analysis showed that Kulfo variety had relatively higher Principal component one (PC1) values, indicating that this variety had the highest average fresh root yield (Figure 1). Tula variety was low yielding but most stable and Beletech was low yielding and least stable. From the result of the relationship among test environments (figure 2), the angles between the two locations: Habro and Mechara were less than $90^{\circ} \mathrm{C}$ and imply that they are positively correlated to one another. In addition, large positive PC1 scores for genotypes indicate that those genotypes had relatively higher mean values [25]. The average environment coordinate (AEC) is the line that passes through the bi-plot origin and separates genotypes with mean values below average and above average [26]. Those genotypes to the right 
of this line are high yielders, while those to the left are low yielders [3].

Since the most stable genotypes are located close to or along the zero line of IPCA ordinates [27]. Stable and high yielding traits are among the major agronomic characteristics required by farmers in sweet potato adoption as such varieties that can have both of these characteristics would likely be accepted by farmers $[28,29]$. Therefore, based on marketable root yield result from two locations, Kulfo varieties were good performance over other variety and standard checks (Figures 1 and 2).

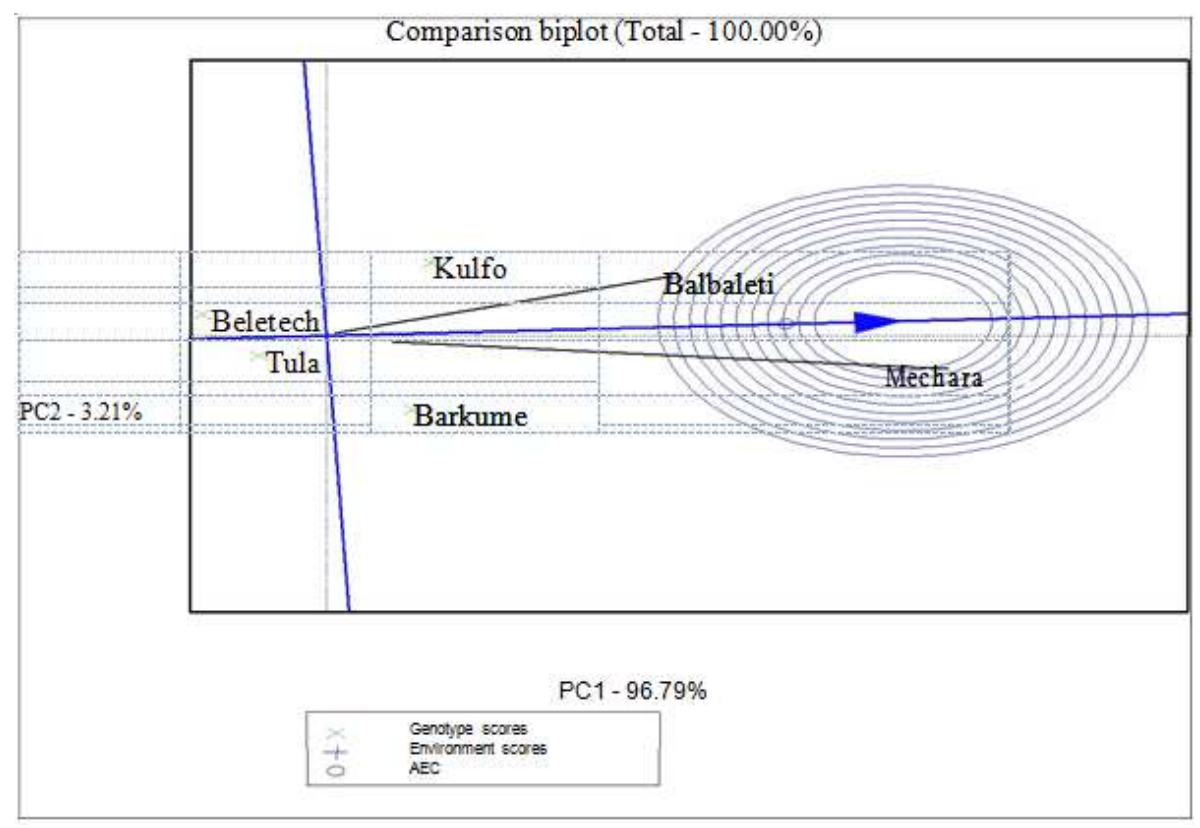

Figure 2. Mean performance of four orange-fleshed sweet potato varieties and their stability across two environments for fresh root yield at West Hararghe zone.

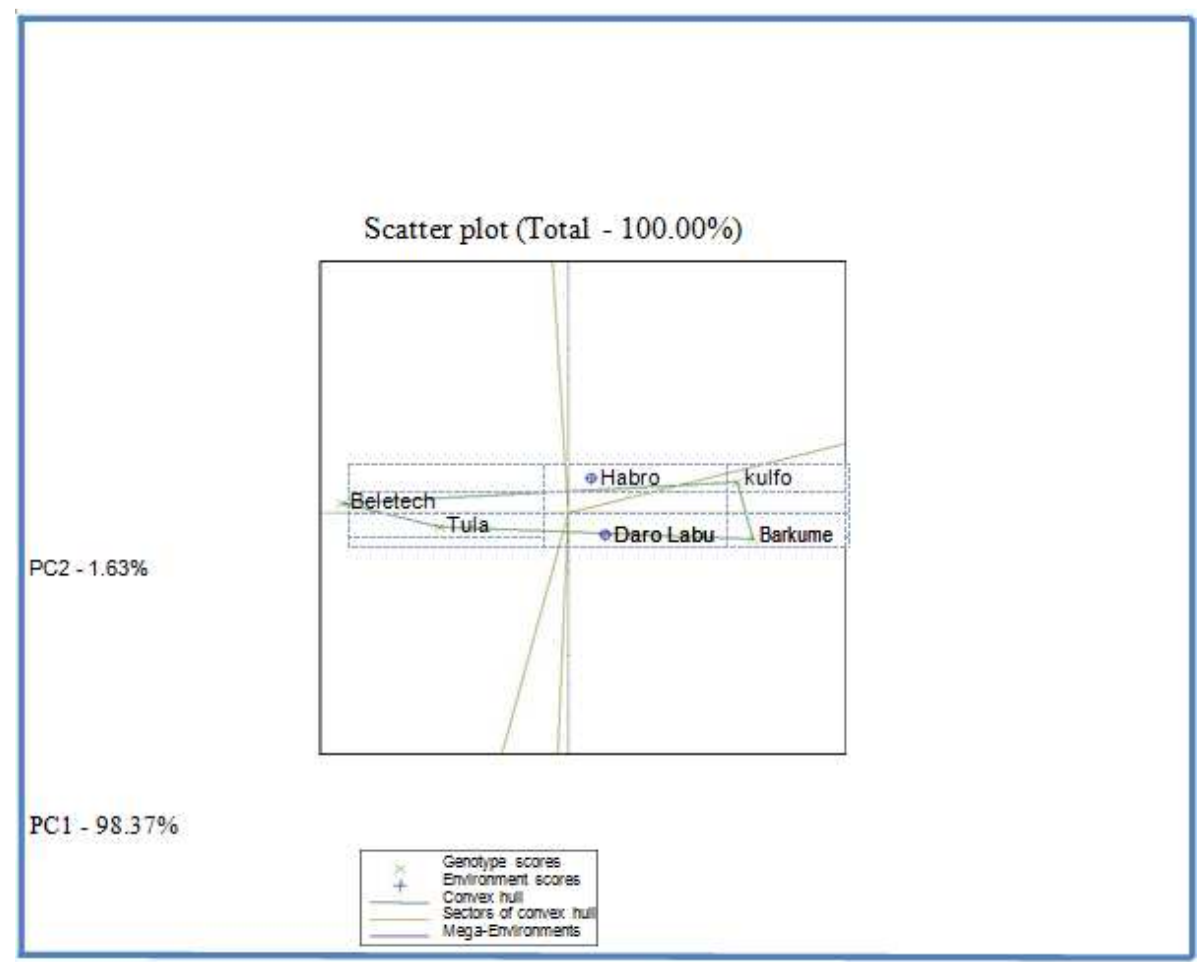

Figure 3. Polygon view of GGE biplot analysis for which-won-where pattern of genotype by environment yield data of orange fleshed sweet potato evaluated at two locations in West Hararghe zone.

Mega environment analysis defines the portioning of the crop growing region into different target zones [30]. The equality line divide the biplot into sectors and the winning genotype is the one located at their respective vertex.
Therefore, kulfo was the vertex angle where Habro fell and thus kulfo was the winning genotype for the Habro location and barkume was the vertex angle where Daro Labu fell and thus barkume was the winning genotype for the Daro Labu 
location (figure 3).

\section{Conclusion and Recommendation}

Three improved varieties (Kulfo, Tulla, and Beletech) including one local check were evaluated with the objective of selecting adaptable and best performing Orange type sweet potato variety in the study area. The experiment was carried out on two districts, West Hararghe zone in 2016 and 2017 cropping season.

The current study results showed that the most important yield and yield contributing parameters: root diameter, number of roots per plant, marketable root yield and total root yield were significantly varied among the orange-fleshed sweet potato varieties evaluated. Kulfo variety was the highest marketable yield across locations while Beletech variety was consistently lowest marketable roots yielding variety. Based on over locations analysis result of marketable root yield from two locations, Kulfo variety was good yield performance over other varieties and local check. The maximum mean marketable yield of improved varieties (15.2 t/ha) in Kulfo variety and $3.75 \%$ yield advantage than the local check. in addition, this genotype had wider adaptability and stability across environments. Therefore, Kulfo variety was potential candidates that could replace local variety, an OFSP variety that is currently grown in West Hararghe zone.

Therefore, Kulfo variety was recommended as the best OFSP variety with optimum yield and highest adaptability in the Eastern part of Ethiopia and potentially combat VAD at community level. Since the findings are based on only three varieties and one check at two locations, further studies using more variety, combination of locations and seasons is required to generate more reliable information on the performance of varieties across the location.

\section{Acknowledgements}

The authors owe a great depth to Oromia Agricultural Research Institute to allocate all necessary budgets for this research. And my depth thanks goes to Mechara Agricultural research center, Center Manager and other Sister Research team, without their assistance and hospitability this paper may not be materialized.

\section{References}

[1] Tortoe, C., M. Obodai and W. Amoa-Awua, Microbial deterioration of white variety sweet potato (Ipomoea batatas) under different storage structures. Int. J. Plant Biol., 1: 10-15, 2010.

[2] Tofu A, Anshebo T, Tsegaye E, Tadesse T, Summary of progress on orange-fleshed Sweet potato research and development in Ethiopia. In: Proceedings of the $13^{\text {th }}$ International Society for Tropical Root Crops (ISTRC) Symposium, Arusha, 9-15 November, 2005, DISTRC, Arusha, Tanzania.

[3] Fekadu Gurmu, Shiferaw Mekonen, Evaluation of root yield performance of newly bred orange-fleshed sweet potato genotypes in Ethiopia. Journal of Agricultural and Crop
Research. Vol. 7 (1), pp. 9-17, 2019.

[4] Kulembeka, H. P., Rugutu, C. K., Kanju, E., Chirimi, B., Rwiza, E. and Amour, R, The agronomic performance and acceptability of orange-fleshed sweet potato varieties in the lake zone of Tanzania. African Crop Sci., 12 (3): 229-240, 2004.

[5] Kapinga R, Anderson P, Crissman C, Zhang D, Lemaga B, Opio F, Vitamin A partnership for Africa: a food-based approach to combat vitamin A deficiency in sub-Saharan Africa through increased utilization of orange-fleshed Sweet potato. Chronica Hortic. 45 (3): 12-14, 2005.

[6] Christina SL, Nutrient and Sensory Quality of Orange Fleshed Sweet potato. MSc Thesis, University of Pretoria, Pretoria. 2007.

[7] Habtu, A., Proceeding of the 25th anniversary of Nazareth agricultural research center: 25years of experience in lowland crops research, September 20-23, 1995. Nazareth Agricultural Research Center, Nazareth, Ethiopia, pp: 36, 1995.

[8] Adhanom, N., A. Tsedeke and G. Emana, Research on Insect Pests of Roots and Roots Crops. In: A Review of Crop Protection Research in Ethiopia: Proceedings of the first Ethiopian Crop Protection Symposium, February 4-7, 1985, Abate, T. (Ed.), Institute of Agricultural Research, Addis Ababa, Ethiopia, 1985

[9] Omiat, E. G., R. E. Kapinga, S. Tumwegamire, T. L. Odong and E. Adipala, On-farm evaluation of orange-fleshed sweetpotato varieties in Northeastern Uganda. Afr. Crop Sci. Conf. Proc., 7: 603-609, 2005.

[10] Low, J. W., M. Arimond, N. Osman, B. Cunguara, F. Zano and D. Tschirley, A food-based approach introducing orange-fleshed sweet potatoes increased vitamin A intake and serum retinol concentrations in young children in rural Mozambique. J. Nutr., 137: 1320-1327, 2007.

[11] Wariboko, C. and I. A. Ogidi, Evaluation of the performance of improved sweet potato (Ipomoea batatas L. LAM) varieties in Bayelsa State, Nigeria. Afr. J. Environ. Sci. Technol., 8: 48-53, 2014.

[12] Anyaegbunam, H. N., G. N. Asumugha, E. O. Mbanasor, T. O. Ezulike and K. I. Nwosu, Guide to improved sweet potato production in Nigeria. National Root Crops Research Institute, approach introducing orange-fleshed sweet potatoes increased vitamin A intake and serum retinol concentrations in young children in rural Mozambique. J. Nutr., 137: 1320-1327, 2008.

[13] Nwankwo, I. I. M., E. E. Bassey and S. O. Afuape, Yield evaluation of open pollinated sweet potato (Ipomoea batatas (L.) Lam) genotypes in humid environment of Umudike, Nigeria. Global J. Biol. Agric. Health Sci., 3: 199-204, 2014.

[14] Siddique, M. A. R, Studies on the morphology, growth and yield of some sweet potato genotypes. M. Sc.(Agriculture) thesis, Dept. of Horticulture, Bangladesh Agricultural University, Mymensingh, 1985.

[15] Belehu T, Agronomical and Physiological Factors Affecting Growth, Development and Yield of Sweet potato in Ethiopia. $\mathrm{PhD}$ Thesis, University of Pretoria, Pretoria, 2003.

[16] Morena, I. A. Guillen, and Garcia del Morel, Yield development in potatoes as influenced by cultivar and the timing and level of nitrogen fertilizer. American Potato Journal. 71: pp. 165-173, 1994. 
[17] Jahan, M. A. and Siddique, M. A. R, Studies on growth, yield and storage of sweet potato as influenced by variety and time of harvest. M. S. Thesis, Dept. of Horticulture, Bangladesh Agricultural University, Mymensingh. 1-84 pp, 2010.

[18] Rahman, M. H., M. M. A. Patwary, H. Barua, M. Hossain and S. Nahar, Evaluation of orange-fleshed sweet potato (Ipomoea batatas L.) genotypes for higher yield and quality. Agriculturists, 11:21-27, 2013.

[19] Bezawit Mekonnen, Solomon Tulu and Jima Nego, Evaluation of Orange Fleshed Sweet Potato (Ipomoea batatas L.) Varieties for Yield and Yield Contributing Parameters in the Humid Tropics of Southwestern Ethiopia. Journal of Plant Sciences 10 (5): 191-199. doi: 10.33495, 2015.

[20] Farooque, A. M. and Husain, A, Studies on the comparative morphological characters and the yield of the seven varieties of sweet potato. Bangladesh Horticulture, 1 (2): 37-44, 1973.

[21] Nedunchezhiyan M, Byju G, Naskar SK, Sweet potato (Ipomoea batatas (L).) as an intercrop in a coconut plantation: growth, yield and quality. J. of Root Crops, 33 (1): 26-29, 2007.

[22] Chataika BYE, Bokosi JM, Kwapata MB, Chirwa RM, Mwale VM, Mnyenyembe P, Myers J R, Performance of parental genotypes and inheritance of Angular Leaf Spot Phaeosariopsi Agricola) resistance in the common bean (Phaseolus vulgaris). Afri. J. Bio. 9 (28): 4398-4406, 2010.
[23] Amare, B., F. Abay and Y. Tsehaye, Evaluation of sweet potato (Ipomea batata L.) varieties for total storage root yield in the south and south-east zones of Tigray, Ethiopia. Am. J. Trade Policy, 1: 74-78, 2014.

[24] Antiaobong, E. E, Life cycle, economic threshold and control of sweet potato weevils, Cylas puncticollis Boh (Coleoptera: Curculionidae) in Akwa Ibom State, Nigeria. PhD Thesis, Michael Okpara University of Agriculture, Umudike Nigeria, pp: 3-5, 2007.

[25] Yan W, Cornelius PL, Crossa J, Huntt LA, Two types of GGE biplots for analyzing multi-environment trial data. Crop Sci. 41: 656-663, 2001.

[26] Yan W, Singular-value partitioning in biplot analysis of multi environment trial data. Agron. J. 94: 990-996, 2002.

[27] Mulema JMK, Adipala E, Olanya OM, Wagoire W, Yield stability analysis of late blight resistant potato selections. Int. Res. J. Agric. Sci. 44, pp. 145-155.392, 2008.

[28] Hassanpanah D, Analysis of GxE interaction by using the additive Main Effects and Multiplicative Interaction in potato cultivars. Int. J. Plant Breed. Genet. 4 (1): 23-29, 2010.

[29] Gauch, H. G. and Zobel, R. W, AMMI analysis of yield trial. In: Kang, M. S. and Gauch, H, G., Eds, genome environment interaction, CRC press, Boca Raton, 85-122, 1996. 